\title{
Effect of the REACT strategy on senior high school students' achievement in molecular genetics
}

\author{
Benedicta Abeka Quainoo, Charles Deodat Otami and Kofi Acheaw Owusu \\ Department of Science Education, University of Cape Coast, Ghana
}

Molecular genetics, a key concept in biology, is found to be very difficult for students at the senior high school level. A situation largely blamed on teachers' instructional approaches. Since the Relating, Experiencing, Applying, Cooperating and Transferring (REACT) strategy is reported to be an effective pedagogical approach for improving students' understanding of science concepts, in this paper, we sought to explore its effectiveness on Senior High School students' achievement in molecular genetics in Ghana. To do this, the embedded mixed methods research design was employed. Two intact biology classes selected through simple random sampling were assigned as experimental and control groups and taught with the REACT strategy and the conventional approach respectively. Quantitative data were obtained with pre-test-post-test control group design and analysed with Independent sample t-test and ANOVA. The qualitative data on students' perception of learning with the REACT strategy was obtained through interviews and analysed thematically. The findings showed that the REACT strategy was more effective for teaching molecular genetics compared with the conventional approach. Although REACT could not bridge the gap between low and high achievers in that group, the performance of low achievers in the REACT group was at par with high achievers in the conventional group. Students perceived the opportunity to search and share information as well as relate new concepts to prior learning provided by the REACT strategy to have facilitated their understanding of concepts in molecular genetics. It is recommended that biology teachers use the REACT strategy to teach concepts students find problematic.

\author{
ARTICLE DETAILS \\ LUMAT General Issue \\ Vol 9 No 1 (2021), 696-716 \\ Received 9 October 2020 \\ Accepted 16 September 2021 \\ Published 22 September 2021 \\ Pages: 21 \\ References: 63 \\ Correspondence: \\ benedicta.quainoo@ \\ stu.ucc.edu.gh
}

https://doi.org/10.31129/ LUMAT.9.1.1418

Keywords: REACT strategy, achievement, high school, molecular genetics

\section{Introduction}

Molecular genetics, which is thought to be the cornerstone of modern biology (Rotbain, Marbach-Ad \& Stavy, 2005; Gericke \& Wahlberg, 2013), continues to be one of the problematic topics for students, especially those at the senior high school level (Marbach-Ad \& Stavy, 2000; Tsui \& Treagust, 2010; Thörne \& Gericke, 2014; Kılıç \& Sağlam, 2014; Aivelo \& Uitto, 2015; Casanoves, Salvadó, González, Valls, \& Novo, 2017). This has been reported in a myriad of studies which showed students at the senior high school level demonstrate a poor understanding of fundamental issues related to molecular genetics (Knippels, Waarlo, \& Boersma, 2005; Kılıç \& Sağlam, 2014; Solé-Llussà, Casanoves, Salvadó, Garcia-Vallve, Valls, \& Novo, 2019). As a result, many biology educators are worried considering the impact knowledge of 
molecular genetics have on science policy decisions such as genetic screening and genetically modified foods (Duncan, Freidenreich, Chinn, \& Bausch, 2011; Freidenreich, Duncan, \& Shea, 2011; Aivelo \& Uitto, 2019; Solé-Llussà, Casanoves, Salvadó, Garcia-Vallve, Valls, \& Novo, 2019).

In Ghana, senior high school students are no exception to poor understanding of fundamental concepts in molecular genetics. This is because the West Africa Examinations Council's Chief Examiners' reports for Senior High School (SHS) elective biology (WAEC, 2011; 2013; 2015; 2016, 2017; 2018), continue to highlight students' poor achievements in concepts related to molecular genetics. Key to students' poor understanding of molecular genetics is the instructional approach adopted by teachers to teach it (Eklund, Rogat, Alozie \& Krajcik, 2007; Thörne \& Gericke, 2014; Kılıç, \& Sağlam, 2014). Therefore, various instructional strategies are suggested in the biology education literature to help address students' difficulties in understanding concepts related to molecular genetics (Rotbain, Marbach-Ad, \& Stavy, 2005; Knippels, Waarolo \& Boersma, 2005; Gericke \& Hageberg, 2010; Gericke \& Smith, 2014; Todd \& Kenyon, 2015; Casanoves, Salvadó, González, Valls, \& Novo, 2017; Nichols; 2018; Solé-Llussà, Casanoves, Salvadó, Garcia-Vallve, Valls, \& Novo, 2019). Examples of which include the use of inquiry games (Casanoves, Salvado, González, Valls, \& Novo, 2017), teaching genetics with developmental biology lens (Stern \& Kampourakis, 2017), using the History and Philosophy of Science ([HPS] approach (Gericke \& Smith, 2014), employing the historical models (Kinnear, 1991; Gericke \& Hagberg, 2010), using computer animation and illustration activities that mirror real-life situations (Marbach-Ad, Rotbain, \& Stavy, 2008), sequencing of genetics content from macro- to micro-levels (Knippels, Waarolo, \& Boersma 2005) and employing drawing-based activity (Rotbain, Marbach-Ad, \& Stavy, 2005). Despite the suggested instructional methods, molecular genetics continue to be challenging for both teachers and students (Gericke \& Wahlberg, 2013; Gericke \& Smith, 2014; Stern \& Kampourakis, 2017). Given the light advances in molecular genetics shed on our daily lives, other instructional approaches with the potential to enhance understanding must be explored.

Consequently, the current Ghanaian Senior High School Biology curriculum prescribes constructivist-based instructional approaches for teachers to foster students' understanding and, thus, their achievement in concepts related to molecular genetics (Curriculum Research and Development Division [CRDD], 2012). Though the Biology curriculum indicates that teachers should employ constructivist-based 
instructional approaches, no specific one is recommended. This leads to a situation where teachers end up employing the conventional approach whereby they take centre stage of the teaching and learning process. Although students may be engaged through the conventional approach, such engagement emanates from the teacher and it is relatively minimal, which does not promote effective conceptual understanding and learning (Preszler, Dawe, Shuster, \& Shuster, 2007). Therefore, it is interesting to explore how a constructivist-based instructional approach will help improve students understanding of molecular genetics in the Ghanaian context.

Since the REACT strategy is reported to be an effective instructional approach for improving students understanding (Günter, 2018; Karsli \& Yigit, 2017; Ültay, Durukan \& Ültay, 2015), it is important that it is tried with Ghanaian senior high school students to find its effects on their achievements in molecular genetics. In our effort to identify the efficacy of the REACT strategy in the Ghanaian educational system, the focus was not paid only to the achievement of students but also their perception of the teaching strategy. The exploration of students' perceptions with regards to the new approach was pertinent because it will bring to the fore students' views on the approach (Beatty \& Albert, 2016), which can affect its acceptance and also aid in planning effective instructional activities (Yoon, Suh, \& Park, 2014). This is because the perceptions students have on instructional approaches are relevant to the teaching and learning process (Tudor, Penlington, \& McDowell, 2010; Johnson, 2016) since students' academic achievement is dependent on the perceptions they have on the teaching and learning strategies employed in the classroom (Knight, 1991; Uiboleht, Karm, \& Postareff, 2019). As elaborated by Ferreira and Santoso (2008), learners tend to perform better when they have positive perceptions about instructional strategies employed in the classroom.

Hence, in this paper, we describe an attempt to improve students' achievement by empirically exploring the efficacy of the REACT strategy on senior high school students' achievements in molecular genetics. In doing so, the REACT strategy was compared with the conventional approach of teaching. To this end, two null hypotheses and a research question were formulated to guide the study:

1. There is no statistically significant difference between the achievement scores of students taught with the REACT strategy and those taught with the conventional approach.

2. There is no statistically significant difference between the achievement scores of high and low achievers within the treatment groups. 
3. What are students' perceptions about the REACT strategy?

\subsection{Theoretical framework}

Our theoretical framework is grounded in social constructivism, which emphasizes understanding/learning through knowledge construction based on social interaction (Kukla, 2000; Gredler, 2009; Vygotsky, 1978). Social constructivism essentially emphasizes the role of collaboration among learners and the experiences they bring to their learning environment (Lave \& Wenger, 1991; McMahon, 1997). Instructional approaches hinged on social constructivism are largely student-centred and foster student collaboration to enhance achievement through peer collaboration, problembased instruction, and learning with others (Schunk, 2000). Though there are various instructional approaches based on social constructivism, one that has the potential to impact science learning is the REACT strategy (Gökalp \& Adem, 2020; Günter, 2018; Ültay \& Alev, 2017; Center for Occupational Research and Development (CORD) 2016).

The REACT strategy is reported to be very effective in teaching and learning science concepts that students find very difficult (Crawford, 2001; Günter, 2018). It was introduced by the Center for Occupational Research and Development (CORD) in the United States of America (CORD, 2016). The name is derived from the first letter of the various stages. ' $\mathrm{R}$ ' is for the relating stage, ' $\mathrm{E}$ ' is for the experiencing stage, ' $\mathrm{A}$ ' is the applying stage, ' $\mathrm{C}$ ' for cooperating and ' $\mathrm{T}$ ' is for transferring stage.

The first stage of the REACT strategy is relating. Here, learners learn in the context of their life experiences or prior knowledge. The learners' attention is drawn to everyday life experiences, and these experiences are then related to new concepts to be learned or a problem to be solved (CORD, 2016). After learners' previous knowledge have been assessed, an enabling environment and the needed materials are given to them to explore. This occurs at the experiencing stage, which is the second stage of the strategy. Crawford (2001) explained that the experiencing stage is to allow learners to experience activities that are related to real-life occurrences as they learn in the context of discovery, exploration and invention. As opined by CORD (2016), the experiencing stage is regarded to be the core of contextual learning and hence, gets students to be interested in learning with respect to text or audiovisual-based activities or both.

After the experiencing stage comes the applying stage, where opportunity is given to learners to apply what they have learned. During the applying stage, learners apply 
the new concepts they have learned or information they have obtained in useful context through class activities, laboratory and project works (Ültay, Güngören, \& Ültay, 2017). At this stage of contextual learning, guidance is given to learners to apply the new knowledge they have obtained in everyday occurrences (CORD, 2016). Since students learn best through collaboration, the teacher must ensure groups are formed for the students to learn in the context of collaborating with their peers. This is done at the cooperating stage, where students learn by sharing, responding and communicating with other learners (CORD, 2016). Learning in groups may result in some students not participating in the process and thus, the purpose of cooperative learning may not be achieved. Consequently, Crawford (2001) noted that teachers should follow the guidelines for cooperative learning for every learner to get involved.

The transferring stage, which comes after cooperating is the final stage of the REACT strategy, where students learn in the context of utilizing the newly learned concepts in a novel setting (CORD, 2016). As reported by Günter (2018), transferring of learning can be done by learners through building upon new concepts they have learned which are familiar to the novel concepts or topic that is to be learned. A critical consideration of all the stages of the REACT strategy reveals that the context-based REACT strategy hinges on social constructivism. This is because the approach takes into consideration learners' prior knowledge, exploration, cooperative learning and transfer of learning which are advocated by proponents of the social constructivist theory.

Various studies have sought to determine the effectiveness of the REACT strategy by comparing it to other instructional approaches. Ültay and Alev (2017) investigated the effect of REACT strategy on pre-service science teachers' learning in collision, impulse and momentum concepts. The study revealed that REACT strategy was significantly more effective than the conventional teaching model in terms of achievement and eliminated students' misconceptions in the concepts taught. In a similar study by Günter (2018) which investigated the effect of REACT strategy on students' achievement in solubility equilibrium, students instructed through the REACT strategy performed better than those who were taught with the conventional approach. A similar finding was obtained by Gökalp and Adem (2020) when they compared the effect of the $5 \mathrm{E}$ model supported with REACT strategy and a computerassisted $5 \mathrm{E}$ model on basic school pupils' achievement on Acids, Bases and Salts. The findings of their study revealed that those taught with the REACT outperformed those 


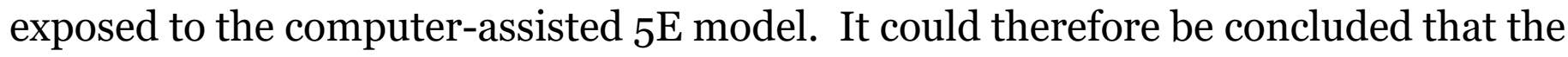
REACT strategy is effective for improving learners' academic performance in science.

Students usually come to the classroom with different conceptions about the new concepts to be learnt, hence some studies have focused on the efficacy of the REACT strategy to help students learn correct concepts and do away with their misconceptions or alternative concepts. A study by Ültay, Durukan and Ültay (2015) brought to light that the REACT strategy was effective in eliminating students' alternative conceptions about concepts on solutions. The effectiveness of the approach in eliminating learners' alternative conceptions is also reported by Karsli and Yigit (2017). They employed a one-group pretest-posttest design to investigate the effect of the REACT strategy on correcting 12th-grade students' alternative conceptions about Alkenes. Their study revealed that the REACT approach to learning was efficient in correcting the learners' misconceptions about alkenes. Günter (2018) confirms the effectiveness of REACT strategy in remedying learners' alternative conceptions about science concepts when she investigated the effect of the REACT instructional approach on students' learning of solubility equilibrium. Her study brought to light that context-based REACT strategy reduced the learners' alternative conceptions about concepts on solubility equilibrium.

Aside from its effect on the learning outcomes, students have been found to have positive perceptions of the REACT strategy as a teaching and learning approach (Günter, 2018; Karsli \& Yigit, 2016). Karsli and Yiğit (2016) conducted a semistructured interview with 12th-grade students after they had been taught concepts on alkanes using a worksheet developed based on REACT strategy. The results of the content analysis of the study showed that the students perceived the alkane worksheet based on REACT strategy to have connected school knowledge with daily life situations, made chemistry lessons interesting, appealing and motivating. A similar result was obtained by Günter (2018) when she investigated the effect of REACT strategy on students' achievement in concepts on solubility equilibrium and then conducted a structured and semi-structured interview on the students' perception about the REACT strategy.

There is enough evidence in the literature to suggest that the REACT strategy would be effective for teaching concepts that are problematic to students. This is because it is reported to be effective in the cognitive domain (Karsli \& Yigit, 2017; Ültay, Güngören, \& Ültay, 2017) and the affective domain (Crawford, 2001; Günter, 
2018; Karsli \& Yigit, 2016). Thus, our attempt to investigate the effectiveness of REACT strategy in the learning of concepts in molecular genetics.

\section{Materials and methods}

\subsection{Research design}

As the study aimed to explore the effectiveness of the REACT strategy on senior high school students' achievement in molecular genetics, an embedded mixed methods research design (Creswell, Plano Clark, Gutmann, \& Hanson, 2003) was adopted. In this design, a qualitative component was embedded in the main quantitative pre-testpost-test non-equivalent control group design. The qualitative aspect was to identify students' perceptions about the REACT strategy to complement the quantitative experimental approach which was used to obtain information on the effect of the strategy on achievement in molecular genetics. The rationale for using the research design was to gain insights into how the REACT strategy could influence Ghanaian senior high school students' achievement in molecular genetics as well as their perception of the approach as an instructional strategy (Hanson, Creswell, Clark, Petska, \& Creswell, 2005; Creswell 2012).

\subsection{Participants}

The participants of this study consisted of 57 senior high school second-year elective Biology students. To obtain the participants, two schools out of five public senior high schools in a school district (Ajumako-Enyan-Essiam) in the Central region of Ghana were selected using a simple random sampling technique. From each of the two selected senior high schools, one intact second-year Biology class was selected using a simple random sampling technique for the study. The two science classes were then randomly assigned to experimental and control groups. The experimental group had 27 students and were instructed with the REACT strategy, while the control group, with 30 students, were taught using the conventional approach on the concepts of molecular genetics. Lesson plans on molecular genetics were developed for the two groups based on their assigned teaching and learning approach (See Appendix 1 \& Appendix 2). Both groups were instructed by the same teacher. The rationale was to make the effect of teacher personality on students' performance constant for the two groups (Huang \& Moon, 2009). The teaching and assessment of students, as indicated 
in the study, took six weeks.

For the qualitative part, 12 students from the experimental group were selected through the stratified random sampling technique for interviews to gauge the students' perception of learning through the REACT strategy. In selecting the students, consideration was given to above average, average and below-average based on their performance in the subject of biology using their biology teachers' classroom assessments. To ensure equal representation of both sexes in the interviews, two males and two females were selected for each of the three categories.

\subsection{Instrument}

To obtain quantitative data for this study, two achievement tests (pre-test and posttest) consisting of 30 multiple-choice items with four answer options were constructed based on the biology syllabus for Ghanaian senior high schools. The pretest was based on "diversity in Living things" which students in both groups had already treated. The posttest items were based on the molecular genetics content treated during the experiment. A semi-structured interview guide was used in collecting the qualitative data (see Appendix 3 for the instruments used in the study).

\subsection{Pilot testing of instrument for quantitative data}

The achievement tests were administered to students in a Senior High School in the Cape Coast Metropolis to determine their reliability. The school used for the pilot testing of the instrument was part of the target population but was not part of the main study. Thirty second-year students took the pre-test and post-test. The students took approximately 60 minutes to complete the tests and the question papers were collected from the students just after the test. Students' scores for the items in the pretest ranged from 10 to 28 and that of the post-test ranged from 8 to 25 . The reliability coefficient for the pre-test was 0.73 and that of the post-test was 0.71 . The KR-20 formula was used to calculate the reliability coefficients. KR-2O was used because the test items were of different levels of difficulty and they were also scored dichotomously. 


\subsection{Quantitative data collection procedure}

Students in the assigned groups were first pretested on "diversity in Living things", which they had already treated. The pre-test was conducted to assess whether the academic achievements of students in the two groups were at par before administering the intervention. The students' scores on the pre-test were also used to categorize the members of each group (i.e., the experimental and control) into low and high achievers. In this study, students whose scores in the pre-test were above the group mean score were classified to be high achievers and those below, designated low achievers. The stratification was to offer an opportunity to gauge whether the REACT could help bring the low achievers up and, thus, bridge the gap between them and the high achievers. Since the conventional instructional approach mostly employed to teach science in Ghanaian classrooms (Yeboah, Abonyi, \& Luguterah, 2019) had not impacted desired learning outcomes and brought lower achievers up (Nwagbo, 2006), we hoped a constructivist approach with attendant cooperating and collaborative tendencies could help low achievers to improve their achievement. After the pre-test, students were instructed molecular genetics with the REACT strategy for the experimental group and the conventional approach for the control group, which lasted for six weeks. The students in both groups were post-tested two weeks after they were taught molecular genetics with the assigned instructional models. Thus, in this study, the content that was taught (molecular genetics) was the same for each group. However, the instructional approach was different for the two groups. The experimental group was instructed through the REACT strategy, while the conventional group were instructed through teacher-centred teaching strategies.

\subsection{Qualitative data collection procedure}

Qualitative information on the perceptions about instruction with the REACT strategy was obtained through a semi-structured interview with the 12 students from the experimental group. The selected students were interviewed for an hour.

\subsection{Quantitative data analysis procedure}

The quantitative data were analyzed using independent samples t-test and one-way analysis of variance (ANOVA). Data for testing the first hypothesis was analyzed with independent samples t-test to ascertain if there was any significant difference between the students in the REACT group and those in the conventional group. The effect size 
was also calculated to identify the practical significance of the statistical result for the difference between the effects of REACT and conventional teaching approaches.

The second hypothesis was tested with a one-way ANOVA to identify if there were differences in the scores of students categorized as high and low achievers in the two groups. Thus, in this hypothesis, there were four groups whose scores were compared against each other.

\subsection{Qualitative data analysis procedure}

To determine the perception of students about the efficacy of the REACT strategy, a semi-structured interview was conducted with the students. The responses obtained were recorded and transcribed. An initial reading was conducted by the researchers independently to categorize the responses into themes. Researchers met to synchronize their categorizations. Four themes emerged ultimately, under which results were presented and discussed.

\section{Results}

\subsection{Results for the analysis of quantitative data}

The first hypothesis sought to determine if there was any statistically significant difference in the achievement scores of students exposed to REACT strategy and the conventional teaching approach. An independent sample t-test was used to analyze the scores with the results presented in Table 1 . The results in Table 1 show that there was no statistically significant difference in the mean score of pre-tests between the students chosen for the two groups. Thus, the performance of the students selected to be in the REACT group and those for the conventional group were at par before the experiment. However, on the post-test scores, the REACT group performed better compared with the conventional group. This indicates that after the experiment, students instructed with the REACT strategy performed better than those instructed through the conventional approach. Therefore, the null hypothesis that there was no statistically significant difference in the achievement scores of students exposed to REACT strategy and the conventional approach was rejected. An effect size index of 1.52 was obtained, which according to Cohen (1988) indicates a large effect size for the difference between the post-test scores of the REACT and the conventional groups. 
Table 1. Results of Independent Sample T-test for pre-test and post-test Scores of the REACT and Conventional Groups

\begin{tabular}{lllllll}
\hline & Group & N & Mean & T & Df & P \\
\hline Pre-test & REACT & 27 & 18.15 & 0.66 & 55 & .947 \\
& Conventional & 30 & 18.07 & & & \\
Post-test & REACT & 27 & 16.48 & 5.647 & 55 & $.001^{*}$ \\
& Conventional & 30 & 11.50 & & & \\
\hline
\end{tabular}

*Significant @ $\mathrm{p}<0.05$.

The second hypothesis sought to find out if there was a statistically significant difference in the scores of the achievement levels (high and low) within the groups. That is, a comparison was made among the high achievers in REACT, low achievers in REACT, high achievers in the conventional group and the low achievers in the conventional group. To be able to ascribe any difference to the treatment, the initial comparisons were made before the experiment. The pre-test scores of the achievement groups were compared using one-way ANOVA. As shown in Table 2, there was a statistically significant difference in the pre-test scores among the groups $(\mathrm{F}(3,53)=30.279, \mathrm{p}<.001)$. Post-hoc comparisons using the Bonferroni test indicated that there was a statistically significant difference in achievement scores between the REACT low achievers $(\mathrm{M}=14.57, \mathrm{SD}=3.502)$ and REACT high achievers $(\mathrm{M}=22.00, \mathrm{SD}=2.677, \mathrm{p}<.001)$. There was no statistically significant difference in achievement scores between REACT low achievers $(\mathrm{M}=14.57, \mathrm{SD}=3.502)$ and conventional low achievers $(\mathrm{M}=14.29, \mathrm{SD}=2.758, \mathrm{p}=1.000)$. There was a statistically significant difference in achievement scores between REACT low achievers $(\mathrm{M}=14.57, \mathrm{SD}=3.502)$ and conventional high achievers' group $(\mathrm{M}=21.38$, $\mathrm{SD}=2.473, \mathrm{p}<$.001) and similar difference was seen in achievement scores between high achievers in the REACT group $(\mathrm{M}=22.00, \mathrm{SD}=2.677)$ and the low achievers in the conventional group $(\mathrm{M}=14.29, \mathrm{SD}=2.758, \mathrm{p}<.001)$. There was no significant difference between the achievement scores of high achievers in the REACT group (M $=22.00, \mathrm{SD}=2.677)$ and the high achievers in the conventional group $(\mathrm{M}=21.38, \mathrm{SD}$ $=2.473, \mathrm{p}=1.000)$. However, there was a significant difference between high achievers in the conventional group $(\mathrm{M}=21.38, \mathrm{SD}=2.473)$ and low achievers in the same group $(\mathrm{M}=14.29, \mathrm{SD}=2.758, \mathrm{p}=.001)$. The results of the pre-test revealed that before the experiment, the high achievers in the REACT and conventional groups were better in terms of achievement scores as compared to the low achievers in both groups. However, the performance of high achievers in both groups was at par. A 
similar non-difference in performance was observed between the low achievers in both groups.

The one-way ANOVA was again used to compare the posttest scores of the groups and the results presented in Table 3. As seen from Table 3, the ANOVA test was statistically significant $(\mathrm{F}(3,53)=25.749, \mathrm{p}<.001)$. The null hypothesis which stated that there is no statistically significant difference in the scores of the achievement groups after the treatments is therefore rejected. To identify where the difference lies, post-hoc comparisons using Bonferroni test was conducted. The Bonferroni test indicated that there was statistically significant difference in the achievement scores between the REACT low achievers $(M=14.07, S D=2.702)$ and the REACT high achievers $(\mathrm{M}=19.08, \mathrm{SD}=2.362, \mathrm{p}<.001)$. There was statistically significant difference in achievement scores between REACT low achievers $(\mathrm{M}=14.07, \mathrm{SD}=$ 2.702) and conventional low achievers $(\mathrm{M}=10.14, \mathrm{SD}=3.134, \mathrm{p}=.002)$. There was no statistically significant difference in achievement scores between REACT low achievers $(M=14.07, S D=2.702)$ and conventional high achievers $(M=13.69, S D=$ 2.600, $\mathrm{p}=1.000)$. The difference between REACT high achievers $(\mathrm{M}=19.08, \mathrm{SD}=$ 2.362) and conventional high achievers $(\mathrm{M}=13.69, \mathrm{SD}=2.600, \mathrm{p}<.001)$ was significant. Again, there was a significant difference between REACT high achievers $(M=19.08, S D=2.362)$ and low achievers in the conventional group $(M=10.14, S D$ $=3.134, \mathrm{p}<.001)$, with similar difference between high $(\mathrm{M}=13.69, \mathrm{SD}=2.600)$ and low achievers $(\mathrm{M}=10.14, \mathrm{SD}=3.134, \mathrm{p}=.008)$ in the conventional group.

Table 2. Results of One-way ANOVA for Pretest of REACT Low, REACT High, Conventional Low and Conventional High Achievers' Groups

\begin{tabular}{llllll}
\hline Sources & $\mathrm{df}$ & Sum of Squares & Mean Squares & $\mathrm{F}$ & $\mathrm{p}$ \\
& & & & & \\
\hline Between Groups & 3 & 747.333 & 249.111 & 30.279 & $.000^{*}$ \\
Within Groups & 53 & 436.036 & 8.227 & & \\
Total & 56 & 1183.368 & & & \\
\hline
\end{tabular}

Table 3. Results of One-way ANOVA for Posttest of REACT Low, REACT High, Conventional Low and Conventional High Achievers' Groups

\begin{tabular}{llllll}
\hline Sources & $\mathrm{df}$ & Sum of Squares & Mean Squares & $\mathrm{F}$ & $\mathrm{p}$ \\
& & & & & \\
\hline Between Groups & 3 & 569.874 & 189.958 & 25.749 & $.000^{*}$ \\
Within Groups & 53 & 391.003 & 7.377 & & \\
Total & 56 & 960.877 & & & \\
\hline
\end{tabular}

*Significant @ p $<0.05$. 


\subsection{Result for the analysis of the qualitative data}

Students were asked to express their views about the REACT strategy, after which their responses were analysed. Four themes emerged from the responses obtained viz understanding of the concept, searching for information, relating concepts to prior learning and sharing of information.

\section{Understanding of Concept}

The students viewed the REACT to have made them understand the concepts they learned. Students responded that it helped to improve their understanding. Student $\mathrm{C}$ argued that "we understood the topic". The approach seems to have also enhanced the confidence and enthusiasm of the students as Student G stated, "I understood the lesson very well and if they give me any test on it, I can answer". Students were so much enthusiastic about the REACT to the extent that they wished it could be used for other topics by their regular teachers, as noted by Student H, who asserted that " $I$ wish all the topics are taught using this approach". These quotes from the students buttress the efficacy of the REACT strategy to improve students' understanding of concepts in molecular genetics, as seen in their achievement scores.

\section{Search for information}

Another aspect of the REACT that students reported on was the ability to search for information. The students asserted that the approach moved away from the teacherled teaching they were used to where the information on the concepts was provided by the teacher. "We obtained a lot of information before we went through the lessons and it helped us to have some idea about the topic" Student B. This was further explained by Student $\mathrm{F}$ that "because we were told to find information on the topic, I searched for a lot of information about the topic... and I got everything taught". Students finding the exploration for information useful is a good trait required for the 21st century. Thus, teachers should build on this to foster inquiry skills and life-long learning in students.

\section{Relating concepts to prior learning}

Students expressed the opinion that they found the idea of linking new concepts to prior learning was very helpful. "In the course of the lesson, what we have already been taught, which is the 'parts of the cell' made the topic easy" Student B. A similar 
view was expressed by Student I that "we have already learnt the Cell so when you introduced it here we easily understood what you were teaching". Although students were not told the stages of the REACT strategy explicitly, they were able to decipher what went on. The ability to relate prior and new learning is a good trait that enhances the transfer of learning. Thus, the REACT strategy seemed to have that innate ability to ensure that students' learning will not be isolated but rather linked and transferred to new situations.

\section{Sharing of information}

Again, the students perceived the REACT strategy to had facilitated information sharing among students. For instance, Student J pointed out that "everybody in my group brought their ideas for us to combine them and so we got more information". Student E also asserted that "being in the group helped us to join our hands together through discussion and had solution to the questions that you gave to us." This means that the REACT strategy allowed the students to take charge of their learning. As a social constructivist strategy, the REACT emphasizes sharing of ideas among students. In view of that students were grouped during the instructional delivery process, and this seemed to have facilitated the sharing of information leading to the maximization of their learning.

The students did not raise any adverse issues regarding their exposure to the REACT strategy. They asserted that "we couldn't see any negative thing about the lessons" Student D. Student F also noted that "all I saw good (sic)" and went on to say that "the teaching style was perfect. There was nothing wrong with it." Student $\mathrm{K}$ also stated that "I did not see anything bad about it. It was good, I hope we will be taught other topic using this method". Although students generally were impressed with the REACT approach, they expressed concern about the duration of the lessons. Student J noted that "the lessons took much time so I don't think my teacher will teach this way". "I don't know if we can cover all the topics if we learn this way" Student L noted. Aside from these misgivings about the duration, the students' perception of the REACT strategy was generally positive which shows that the REACT is an effective strategy that biology teachers could employ to teach concepts in molecular genetics. 
The results of the study showed that students in the REACT group performed better than their colleagues in the conventional group on the post-test implying that the REACT strategy can improve Senior High School students' performance in molecular genetics. This finding is similar to those of (Günter, 2018; Karsli \& Yigit, 2017; Ültay, Durukan, \& Ültay, 2015), who reported that students who were exposed to the REACT strategy performed better than those who were exposed to the conventional approach. Also, Ültay and Çalik (2016) compared the effect of REACT strategy, 5 E learning cycle and traditional approach on Turkish pre-service science teachers' learning of acid and base. Their study revealed that REACT strategy was the most efficient among the three approaches in retaining concepts that have been learned in long term memory.

Effective teachers seek to improve the performance of all students. The conventional approach, which has characterised classroom instruction in Ghana (Yeboah et al., 2019) has been found to consistently improve the performance of high achievers leading to an increasing achievement gap between students. The REACT strategy, being a constructivist approach with its associated elements of cooperation and collaboration, was anticipated to possess the ability to prop up the achievements of the low achievers. However, in this current study, the REACT strategy could not bridge the gap between the low and high achievers within that group. This is similar to the findings of Jelatu, Sariyasa and Ardana (2018) when they found that the REACT strategy led to the higher achievement of high ability students compared with low ability students in the of understanding concepts in geometry.

Although the low achievers in the REACT group could not close the achievement gap between them and their high achieving counterparts in the group, they were able to match the performance of students in the conventional group. The evidence points to the fact that the performance of the low achievers in the REACT group was at par with that of the high achievers in the conventional group after the treatment. This is a tremendous improvement since before the intervention, the high achievers in the conventional group had higher achievement scores than the low achievers in the REACT group. Since these groups of students differed only in the interventions provided, it is not farfetched to attribute the improvement of performance in the low achievers in the REACT group to the approach used to instruct them. Thus, it seems the REACT approach helped the low achievers in that group as compared to the influence of the conventional approach on low achievers. 
Various aspects of the REACT strategy can help low achievers to understand the concepts being taught better, thereby leading to improved learning outcomes. For instance, the cooperating phase of the REACT strategy comes with inherent properties whereby students mediate and prop up colleagues' learning ensuring that all succeed (Johnson \& Johnson, 1999; Slavin, 1995). Moreover, cooperating in the classroom among learners comes with positive interdependence and individual accountability, which tends to improve students' learning (Johnson \& Johnson, 1999; Slavin, 1995). Thus, in general, students cooperating during learning tend to achieve better scores (Kagan \& Kagan, 2009).

It could, therefore, be concluded that the REACT strategy is effective in improving the overall achievement of students compared with the conventional approach. Although both approaches could not help in lowering the gap in achievements between low and high achieving students concerning learning of concepts in molecular genetics within each group, there seemed to be an improvement of the achievement of low achievers in the REACT group when compared to high and low achievers in the control group. Thus, the REACT approach has the potential of improving the performance of low achievers more than the conventional approach.

Students' perceptions about learning Biology in one way or the other influence their achievement in the subject. Since Ghanaian students' attitudes towards Biology have not been encouraging (Yawson et al., 2016), any teaching model that is capable of arousing students' interest in learning the subject can be employed in the classroom. The current study found that the REACT strategy made molecular genetics lessons interesting, as it helped students to understand the concepts well (Karsli \& Yigit, 2016; Ültay, Durukan, \& Ültay, 2015), facilitated collaboration amongst the students as well as improved students' skills for information search. This finding is similar to that of Günter (2018) when students noted that the REACT strategy made them understand the concepts taught, related the new concepts to what they already know and aided them to share information. 


\section{Conclusion and implications}

\subsection{Conclusion}

Based on the findings of this research, it can be concluded that the REACT strategy is more effective compared with the conventional approach in improving students' academic achievement in molecular genetics. It is also concluded based on the findings that the REACT strategy could not bridge the gap between the achievement of low and high achievers, just like the case for the conventional approach. The inability of the teaching approaches to bridge the gap between the performance of low and high achievers could be due to the difference in the individual construction of knowledge and the difference in the innate ability of students to achieve academically. Again, it can be concluded that students had positive perceptions about the REACT strategy despite the duration it took to complete the lessons.

\subsection{Implications for practice}

The current study has revealed another constructivist-based model of teaching that can be used in the Ghanaian context to teach concepts in molecular genetics at the Senior High School level. As a result, the REACT strategy can be prescribed in the Biology curriculum for teachers to willfully employ in their instruction to improve students' achievement in the subject.

Further, the REACT strategy could be used as a means to increase the declining interest of students to pursue Biology and its related courses since it is capable of increasing students' motivation to learn the subject. Moreover, since the strategy improved collaboration among students, teachers could use the REACT to help develop collaboration skills among students.

\section{Acknowledgements}

The funding of this research work was supported by the Samuel and Emelia BrewButler - SGS/GRASAG, UCC Research Grant. 


\section{References}

Aivelo, T., \& Uitto, A. (2015). Genetic determinism in the Finnish upper secondary school biology textbooks. Nordic Studies in Science Education,11(2), 139-152, DOI: https://doi.org/10.5617/nordina.2042

Aivelo, T., \& Uitto, A. (2019) Teachers' choice of content and consideration of controversial and sensitive issues in teaching of secondary school genetics. International Journal of Science Education, 41(18) 2716-2735, https://doi.org/10.1080/09500693.2019.1694195

Beatty, B. J., \& Albert, M. (2016). Student perceptions of a flipped classroom management course. Journal of Applied Research in Higher Education, 8(3), 316-328. https://doi.org/10.1108/JARHE-09-2015-0069

Casanoves, M., Salvadó, Z., González, Á., Valls. C., \& Novo, M. T. (2017). Learning genetics through a scientific inquiry game. Journal of Biological Education, 51(2), 99-106, https://doi.org/10.1080/00219266.2016.1177569

Center for Occupational Research and Development (CORD). (2016). The REACT learning strategy. Retrieved from http://cordonline.net/CTLtoolkit/downloads/REACT\%2oflyer\%20ABE_revised\%2ofooter. pdf

Cohen, J. (1988). Statistical power analysis for the behavioral sciences (2nd ed.). Hillside, NJ: Erlbaum.

Crawford, M. L. (2001). Teaching contextually: Research, rationale and techniques for improving student motivation and achievement in mathematics and science. Waco, Texas: CCI Publishing.

Creswell, J.W. (2012). Educational research - planning, conducting, and evaluating quantitative and qualitative research (4nd ed.). Boston: Pearson Education.

Creswell, J. W., Plano Clark, V. L., Gutmann, M. L., \& Hanson, W. E. (2003). Advanced mixed methods research designs. In A. Tashakkori \& C. Teddlie (Eds.), Handbook of Mixed Methods in Social and Behavioral Research (pp. 209-240). Thousand Oaks, CA: Sage.

Curriculum Research and Development Division (CRDD). (2012). Teaching syllabus for biology. Accra, Ghana: Ghana Education Service.

Duncan, R.G., Freidenreich, H.B., Chinn, C.A., Bausch, A. (2011). Promoting middle school students' understandings of molecular genetics. Res. Sci. Educ., 41, 147-167 https://doi.org/10.1007/s11165-009-9150-0

Eklund, J., Rogat, A., Alozie, N., \& Krajcik, J. (2007, April). Promoting student scientific literacy of molecular genetics and genomics. In Annual Meeting of the National Association for Research in Science Teaching, April 2007, New Orleans.

Ferreira, A., \& Santoso, A. (2008). Do student perceptions matter? A study of the effect of student's perceptions on academic performance. Accounting and Finance, 48, 209-231. https://doi.org/10.1111/j.1467-629X.2007.00239.x

Freidenreich, H. B., Duncan R. G., \& Shea, N. (2011). Exploring middle school students' understanding of three conceptual models in genetics. International Journal of Science Education, 33(17), 2323-2349. https://doi.org/10.1080/09500693.2010.536997

Gericke, N. \& Hageberg, M. (2010). Conceptual incoherence as a result of the use of multiple historical models in school textbooks. Research in Science Education, 40, 605-623.

Gericke, N., \& Smith, M. U. (2014). Twenty-first-century genetics and genomics: contributions of HPS informed research and pedagogy. In Matthews, M. R. (Ed.), International handbook of research in history, philosophy and science teaching (Vol. I, pp. 423-467). Dordrecht: Springer. 
Gericke, N \& Wahlberg, S. (2013) Clusters of concepts in molecular genetics: a study of Swedish upper secondary science students understanding, Journal of Biological Education, 47 (2), 73-83. https://doi.org/10.1080/00219266.2012.716785

Gökalp, F., \& Adem, S. (2020). The effect of REACT and computer-assisted instruction model in $5 \mathrm{E}$ on student achievement of the subject of acids, bases and salts. Journal of Science Education and Technology, 29, 658-665. https://doi.org/10.1007/s10956-020-09844-6

Gredler, M. E. (2009). Learning and instruction: Theory into practice. (6th ed). New Jersey: Pearson

Günter, T. (2018). The effect of the REACT strategy on students' achievements with regard to solubility equilibrium: Using chemistry in contexts. Chemistry Education Research and Practice, 19(4), 1287-1306. https://doi.org/10.1039/C8RP00087E

Hanson, W. E., Creswell, J. W., Clark, V. L. P., Petska, K. S., \& Creswell, J. D. (2005). Mixed methods research designs in counseling psychology. Journal of Counseling Psychology, 52(2), 224-235. https://doi.org/10.1037/0022-0167.52.2.224

Huang, F. L., \& Moon, T. R. (2009). Is experience the best teacher? A multilevel analysis of teacher characteristics and student achievement in low performing schools. Educational Assessment, Evaluation and Accountability, 21(3), 209-234.

Jelatu, S. Sariyasa, S., \& Ardana, I. M (2018). Effect of GeoGebra-aided REACT strategy on understanding of geometry concepts. International Journal of Instruction, 11(4), 325-336. Retrieved from https://files.eric.ed.gov/fulltext/EJ1191656.pdf

Johnson, A. D. (2016). The relationship between student perceptions of school effectiveness and student achievement: Implications for educational planning. Educational Planning, 23(2), $31-43$.

Johnson, D. W., \& Johnson, R. T. (1999). Learning together and alone: Cooperative, competitive, and individualistic learning. (6th ed.). Boston: Allyn \& Bacon.

Kagan, S., \& Kagan, M. (2009). Kagan cooperative learning. San Clemente: Kagan publishing

Karsli, F., \& Yiğit, M. (2016). 12 ${ }^{\text {th }}$ grade students' views about an alkanes worksheet based on the REACT strategy. Necatibey Faculty of Education Electronic Journal of Science \& Mathematics Education, 10 (1), 472-499.

Karsli, F., \& Yigit, M. (2017). Effectiveness of the REACT strategy on 12th grade students' understanding of the alkenes concept. Research in Science \& Technological Education, 35(3), 274-291. https://doi.org/10.1080/02635143.2017.1295369

Kılıç, D., \& Sağlam, N. (2014). Students' understanding of genetics concepts: The effect of reasoning ability and learning approaches. Journal of Biological Education,48(2), 63-70, https://doi.org/10.1080/00219266.2013.837402

Knight, S. L. (1991). The effects of students' perceptions of the learning environment on their motivation in language arts. The Journal of Classroom Interaction, 26(2), 19-23.

Kukla, A. (2000). Social constructivism and the philosophy of science. Philosophical issues in Science. London: Routledge.

Knippels, M. P. J., Waarlo, A. J., \& Boersma, K. T. (2005). Design criteria for learning and teaching genetics. Journal of Biological Education, 39(3), 108-112, https://doi.org/10.1080/00219266.2005.9655976

Lave, J., \& Wenger, E. (1991). Situated learning: Legitimate peripheral participation. London: Cambridge university press.

Marbach-Ad, G., \& Stavy, R. (2000). Students' cellular and molecular explanations of genetic phenomena. Journal of Biological Education, 34(4), 200-205, https://doi.org/10.1080/00219266.2000.9655718 
Marbach-Ad, G., Rotbain, Y., \& Stavy, R. (2008). Using computer animation and illustration activities to improve high school students' achievement in molecular genetics. Journal of Research in Science Teaching, 45, 273-292.

McMahon, M. (1997, December). Social constructivism and the World Wide Web-A paradigm for learning. In ASCILITE conference. Perth, Australia (Vol. 327).

Nichols, K. (2018). Impact of professional learning on teachers' representational strategies and students' cognitive engagement with molecular genetics concepts. Journal of Biological Education, 52(1), 31-46. https://doi.org/10.1080/00219266.2017.1285800

Nwagbo, C. (2006). Effects of two teaching methods on the achievement in and attitude to biology of students of different levels of scientific literacy. International Journal of Educational Research 45(3), 216-229

Preszler, R. W., Dawe, A., Shuster, C. B., \& Shuster, M. (2007). Assessment of the effects of student response systems on student learning and attitudes over a broad range of biology courses. CBE-Life Sciences Education, 6(1), 29-41.

Rotbain, Y., Marbach-Ad, G., \& Stavy, R. (2005). Understanding molecular genetics through a drawing-based activity. Journal of Biological Education, 39(4), 174-178, https://doi.org/10.1080/00219266.2005.9655992

Slavin, R. E. (1995). Cooperative learning. (2nd ed.). Boston: Allyn \& Bacon.

Solé-Llussà, A., Casanoves, M., Salvadó, Z., Garcia-Vallve, S., Valls, C., \& Novo, M. (2019). Annapurna expedition game: Applying molecular biology tools to learn genetics. Journal of Biological Education, 53(5), 516-523. https://doi.org/10.1080/00219266.2018.1501409

Stern F., \& Kampourakis, K. (2017). Teaching for genetics literacy in the post-genomic era. Studies in Science Education, 53 (2), 193-225.

Schunk, D. (2000). Learning theories: An educational Perspective (2nd ed). New Jersey: Prentice- Hall, Inc

Thörne, K. \& Gericke, N. (2014). Teaching genetics in secondary classrooms: A linguistic analysis of teachers' talk about proteins. Research in Science Education, 44, 81-108. https://doi.org/10.1007/s11165-013-9375-9

Todd, A., \& Kenyon, L. (2015). Empirical refinements of a molecular genetics learning progression: The molecular constructs. Journal of Research in Science Teaching, 53 (9), 1385-1418. https://doi.org/10.1002/tea.21262

Tsui, C., \& Treagust, D. (2010). Evaluating secondary students' scientific reasoning in genetics using a two-tier diagnostic instrument. International Journal of Science Education, 32 (8), 1073-1098. https://doi.org/10.1080/09500690902951429

Tudor, J., Penlington, R., \& McDowell, L. (2010). Perceptions and their influences on approaches to learning. Engineering Education, 5(2), 69-79.

https://doi.org/10.11120/ened.2010.05020069

Uiboleht, K., Karm, M., \& Postareff, L. (2019). Relations between students' perceptions of the teaching-learning environment and teachers' approaches to teaching: A qualitative study. Journal of Further and Higher Education, 43(10), 1456--1475.

https://doi.org/10.1080/0309877X.2018.1491958

Ültay, E., \& Alev, N. (2017). Investigating the effect of the activities based on explanation assisted REACT strategy on learning impulse, momentum and collisions topics. Journal of Education and Practice, 8(7), 174-186.

Ültay, N., \& Çalik, M. (2016). A comparison of different teaching designs of acids and bases' subject. Eurasia Journal of Mathematics, Science \& Technology Education, 12(1).

Ültay, N., Durukan, Ü. G., \& Ültay, E. (2015). Evaluation of the effectiveness of conceptual change texts in the REACT strategy. Chemistry Education Research and Practice, 16(1), 22-38. https://doi.org/10.1039/C4RPo0182F 
Ültay, N., Güngören, S. Ç., \& Ültay, E. (2017). Using the REACT strategy to understand physical and chemical changes. School Science Review, 98(364), 47-52.

Vygotsky, L. S. (1978). Socio-cultural theory. Mind in society, 6, 52-58.

West African Examinations Council [WAEC]. (2011). Chief examiners' reports: May/June West Africa Senior Secondary School Certificate Examination. Accra, Ghana: Author.

West African Examinations Council [WAEC]. (2013). Chief examiners'reports: May/June West Africa Senior Secondary School Certificate Examination. Accra, Ghana: Author.

West African Examinations Council [WAEC]. (2015). Chief examiners'reports: May/June West Africa Senior Secondary School Certificate Examination. Accra, Ghana: Author.

West African Examinations Council [WAEC]. (2016). Chief examiners' reports: May/June West Africa Senior Secondary School Certificate Examination. Accra, Ghana: Author.

West African Examinations Council [WAEC]. (2017). Chief examiners'reports: May/June West Africa Senior Secondary School Certificate Examination. Accra, Ghana: Author.

West African Examinations Council [WAEC]. (2018). Chief examiners' reports: May/June West Africa Senior Secondary School Certificate Examination. Accra, Ghana: Author.

Yawson, N. A., Amankwaa, A. O., Tali, B., Shang, V. O., Batu, E. N., \& Asiemoah, K. (2016). Evaluation of changes in Ghanaian students' attitudes towards science following neuroscience outreach activities: A means to identify effective ways to inspire interest in science careers. Journal of Undergraduate Neuroscience Education, 14(2), A117-A123.

Yeboah, R., Abonyi, U. K., \& Wontepaga, A. (2019). Making primary school science education more practical through appropriate interactive instructional resources: A case study of Ghana, Cogent Education, 6, 1611033.

Yoon, S. Y., Suh, J. K. \& Park, S. (2014). Korean Students' Perceptions of Scientific Practices and Understanding of Nature of Science. International Journal of Science Education, 36(16), 2666-2693. 